International Journal of Linguistics, Literature and Translation (IJLLT)

ISSN: 2617-0299 (Online); ISSN: 2708-0099 (Print)

DOI: $10.32996 / \mathrm{ijllt}$

Journal hompage: www.al-kindipublisher.com/index.php/ijllt/index

\title{
Bridging the Cultural Divide: A Study of the Published English Versions of Some of Gamal Al- Ghitani Literary Works
}

Amr Nour El Din ${ }^{1 *}$ and Dheya S. Al-Jalahma ${ }^{2}$

${ }^{1}$ Assistant Prof. of Translation Studies, College of Arts, University of Bahrain, Kingdom of Bahrain

${ }^{2}$ Assistant Prof. of Translation Studies, College of Arts, University of Bahrain, Kingdom of Bahrain

Corresponding Author: Amr Nour El Din, E-mail: amrlicu@yahoo.com

ARTICLE INFO

Received: November 12, 2020

Accepted: December 10, 2020

Volume: 3

Issue: 12

DOI: 10.32996/ij|lt.2020.3.12.1

\section{KEYWORDS}

The semantic approach, the communicative approach, equivalence, Skopostheorie, Functionalism, Gamal AlGhitani.

\section{ABSTRACT}

This research paper is an attempt to evaluate Peter Newmark's semantic and communicative approaches that are commonly adopted by translators to impart the flavor of the Egyptian culture to the Anglophone readers. The two approaches are diametrically opposed: the semantic approach involves the transfer of the text literally without any alteration: it preserves the length of sentences, position and integrity of clauses and words. It is author-oriented in the sense that it closely pursues the author's thought process and disregards the response of the target readers. This approach does not pay heed to the message of the writer and the target readers may find it difficult to digest the target text. The communicative approach, on the other hand, sets great store on the target reader and the response of the receptor. It attempts to generate a meaning that will elicit a response from the target recipients that approximates the response of the SL readers. It also advocates the equivalent-effect principle of translation which tends to rule out the predominance of words and structure. This paper attempts to address the vexed question of choosing an optimal translation approach and whether to represent the source culture in Target Text by highlighting the importance of the functional approach to translation which is based on the Skopostheorie, for it strikes a balance between Newmark's approaches by according priority to the function the translated text is intended to fulfill. Although this Skopostheorie has drawn many criticisms, some of them have been refuted; it is practically useful to adopt it provided the translator voices his/her opinion which is soundly based on his/her expertise and does not follow blindly what the commissioner/client dictates to him/her. Translation is not all about linguistic transcoding, or cultural transference, rather it is a communicative action determined by a purpose. Translators can safely produce skopos-based translation provided that they observe the principles of coherence and culture. Some of Gamal Al-Ghitani's literary works are selected to put theories into practice since they are replete with expressions that reflect the Egyptian culture hence pose a challenge to the translator.

\section{Introduction}

Al-Ghitani (1945-2015) is one of the accomplished Egyptian novelists and short story writers whose fiction has won the acclaim of critics and readers alike because it occupies the interface between the social, the political and the psychological. He follows in the footsteps of the late Nobel laureate Naguib Mahfouz in his inveterate love for classical Arabic and folkloric legacy. Hence, his corpus poses considerable difficulty to the translator since it is impregnated with culture-specific expressions that reflect the Egyptian cultural milieu. Each word or phrase in Arabic has its physical form and its peculiar connotations, and these can never be duplicated with complete accuracy in English. Hatim and Mason (1997) delineate the onerous role of translators by saying that

To say that translators communicate may perhaps strike one as a fairly obvious claim to make. Yet, it is this very quest for the successful exchange of meanings that is at the heart of what we 
pursue as professional or trainee translators, teachers or critics of translation. Typically, one might say of translators that they are constantly exchanging something, not only by engaging in a dialogue with a source text producer and a likely target text receiver, but also by brokering a deal between the two parties to communicate across both linguistic and cultural boundaries.

The task of choosing the appropriate translation approach devolves wholly on the translator. S/he sifts through the various approaches and arrives at a decision. Landers (2001) alerts translators that "literary translation entails an unending skein of choices"(9). The translator is thus faced with a range of choices, from which s/he should carefully choose, as this would affect his/her end product, translation, and be a contributory cause of its success. Rose (1981) asserts:

Translators, more often than not, work intuitively and, for the most part, alone. Their choices, even when made routinely through long experience, are made in terms of what sounds right for the text at hand. If they are sure of their choices, they can probably defend them. Yet the fact remains that before a given translation is entirely completed, another mind or minds must be brought to bear. The process itself optimally requires it. (1)

Admittedly, culture places the translator in a predicament: $s /$ he ponders over the appropriate approach s/he can adopt to impart the cultural flavor of the Source Text (ST) to the target recipients safely without running the risk of producing a Target Text (TT) that may seem alien to them. In so doing, the translator may safely assume that adopting the semantic approach could drive home the message s/he seeks to put across. Newmark (1988) maintains " A semantic translation attempts to recreate the precise flavor and tone of the original: the words are 'sacred' not because they are more important than the content, but because form and content are one" (47).

Thus, semantic translation involves the transfer of the text literally without much alteration: it preserves the length of sentences; position and integrity of clauses and words. It is author-oriented in the sense that it closely pursues the author's thought process and disregards the response of the target readers. This approach does not pay heed to the message of the writer and the target readers may find it difficult to digest the target text. Newmark asserts that " A semantic translation attempts to preserve its author's idiolect; his peculiar form of expression...in semantic translation every word translated represents loss of meaning" (Ibid: 47).

The following instance amply illustrates how semantic translation seeks to stay within the thought process of the author:

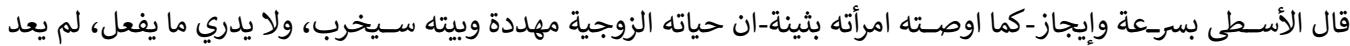

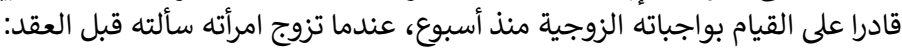

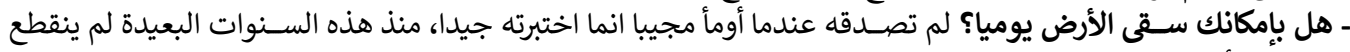

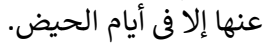

The Usta spoke quickly and, just as his wife had instructed, came straight to the point, saying that his marital life was in jeopardy, that his home was falling apart, and that he did not know what to do. He was no longer able to fulfill his conjugal duties, and this had already lasted a week. When he was engaged to be married, but before signing the contract, his fiancée, as she then was, had asked him specifically, "Can you water the soil, daily?" Refusing to believe his nod of affirmation, she had tested him thoroughly. For many years, apart from the days of her period, he had not ceased. (The Zafarani Files, 4)

Adopting semantic translation, the translator renders the pun هل بإمكانك سقى الأرض يوميا into Can you water the soil, daily?, overlooking the fact that Arabic and English do not have interpretive resemblance and compromising the comprehensibility of the $T$, as this incident is one of the significant propellers of action in the novel under study. It is likely that the target readers will experience great difficulty in decoding the meaning of the pun at hand and re-encode it in their language. The translator sacrifices comprehensibility at the expense of sticking to the author's rhetorical devices. Beekman and Callow (1974) point out:

In every text that one may want to translate, there will be information which is implicit; that is, it is not stated in an explicit form in the text itself. Some information or meaning is left implicit because it has already been included elsewhere in the text, and some because of shared 
information in the communication situation. However, the implicit information is part of the meaning which is to be communicated by the translation, because it is part of the meaning intended to be understood by the original writer. (132)

Employing the semantic approach, the translator may fall short of getting his/her message across because of the cultural discrepancies between English and Arabic, as s/he deals with words and disregards the effect of these words on the target readers. The problem this approach poses is that the words of the source text will not have the same effect in the target culture because of the vast difference that exists between English and Arabic in terms of culture. The translator should always bear this difference in mind lest his/her translated text should be open to misconstruction. The following example attests to this fact:

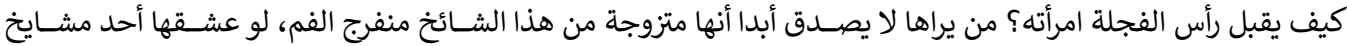

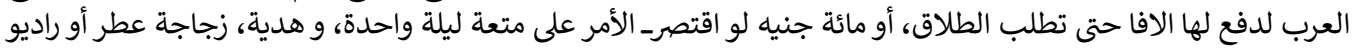

$$
\begin{aligned}
& \text { ترانزستور مع ريكوردر كاسيت، لكن ما العمل و هو يعطى الطيه لالحلق للى بلا وداني). }
\end{aligned}
$$

How did Radish-head kiss his wife? Anyone seeing her would never believe that she is married to this ageing, open-mouthed man. If a rich Arab were to fall in love with her, he'd pay her thousands to seek a divorce or a hundred pounds for one night's pleasure, plus a gift such as a bottle of perfume or a transistor radio with a cassette recorder. But what was to be done when the Lord, in His wisdom, gave earrings to those who have no ears? (The Zafarani Files, 75)

The translator, Farouk Abdel Wahab, has attached a greater importance to the words than the message he is supposed to put across to the target recipients. Adhering to the semantic approach in rendering هو يعطى (الحلق للى بلا ودان) into "when the Lord, in His wisdom, gave earrings to those who have no ears?", he has produced an odd-sounding expression. He may justify opting for the semantic approach that he seeks to enable the target recipients to savour the Egyptian culture with its peculiarities. Newmark maintains that "semantic translation attempts to render, as closely as the semantic and syntactic structures of the second language allow, the exact contextual meaning of the original" (ibid: 39).

Had the translator opted for the expression "the gods send nuts to those who have no teeth", he would have elicited the equivalent response, and spared himself the difficulty of adding the words "when the Lord, in His wisdom", which have a disconcerting effect on the target readers. The addition of such words exhibits one of the characteristic symptoms of adopting the semantic approach; namely, the tendency to "overtranslate". This tendency stems from the loss of the ST meaning and the difficulty of finding an exact equivalent for a given word or more generally because the writer of ST and the translator favour different phraseology. Newmark contends that "a semantic translation tends to be more complex, more awkward, more detailed, more concentrated, and pursues the thought-processes rather than the intention of the transmitter. It tends to over translate, to be more specific than the original, to include more meanings in its search for one nuance of meaning" (39).

Many translators tend to employ the semantic approach because they are so overwhelmed with their own native culture that they lose sight of the exact equivalents in the target culture. Translators should exhibit a degree of flexibility lest they should misinterpret the text at hand. Hatim and Mason (1990) alert translators to this problem by asserting that "Inevitably, we feed our own beliefs, knowledge, attitudes and so on into our processing of texts, so that any translation will, to some extent, reflect the translator's own mental and cultural outlook, despite the best impartial intentions" (11).

In the same connection, Brown (2004:28) sternly warns translators against what he calls being "linguistically schizophrenic", that is, translators are sometimes deceived into believing that the structure they have reproduced is correct simply because it is correct in the source language, or they even take pains to reproduce idioms and expressions though they already exist in the cultural matrix of TL and SL without alteration. The following two examples serve as a true pointer to the magnitude of this problem:

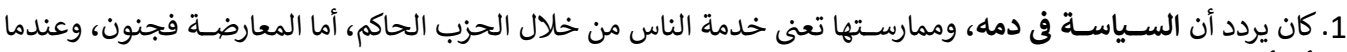

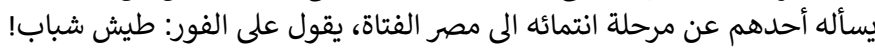

1. He repeatedly said that politics was mother's milk to him. And for him, it meant rendering services to the people through the ruling party. Opposition was madness. What about Masr ElFatah, an avowedly opposition party? 
"Ah, well," he'd say, "youthful folly!" (A Distress Call, 81)

$$
\text { 2. ليست المرة الأولى يا أستاذ، كلك نظر، انه مجرد اجراء روتينى.. أيام قليلة وينتهي كل شيء.. }
$$

2. "It is not the first time you've been followed, sir; you know all about these things. You know it's just routine procedure; it'll be all over in a day or two." (A Distress Call, 219)

In the first example, the translator, Soad Naguib, has hastened to find an equivalent to the Arabic idiom, overlooking the fact that the same idiom exists in English; namely "in one's blood". In the second example, Naguib seems to be so immersed in the SL that she has mistakenly opted for the collocation "routine procedure". This error can also be attributed to the fact that the word "routine" is naturalized into Arabic. Had she opted for the adjective "standard" which collocates with "procedure", she would have produced a fluent text. Baker (1991) points out that "a translator can easily misinterpret a collocation in the source text due to interference from his \her native language. This happens when a source-language collocation appears to be familiar because it corresponds in form to a common collocation in the target language" (55).

Further, the above-mentioned example delineates the impact of foisting the SL culture on target recipients: the semantic distortion ensued from rendering هو يعطى (الحلق للى بلا ودان) alerts the translators to the fact that more attention should be paid to the content of the message than the form. The form is invariably adjusted because of the cultural distance existing between Arabic and English. Bassnett and Lefevere (1990) strongly advise that

To attempt to impose the value system of the SL culture onto TL culture is a dangerous ground, and the translator should not be tempted by the school that pretends to determine the original intentions of an author on the basis of a self-contained text. The translator cannot be the author of the SL text, but as the author of the TL text has a clear moral responsibility to TL readers. (23)

SL authors, on the other hand, may lean toward the semantic approach on the grounds that it retains the aesthetic and artistic essence of the original, which is in fact the fruit of their rigorous research orientation and philosophical musings. They also contend that the translator should respect their lexical and grammatical idiosyncrasies since each word they use is charged with meaning. However, adhering to this approach may prove detrimental to authors, as it may render their works of art inaccessible to TL readers, and consequently dim their prospects of exposure and monetary reward. Newmark argues:

The transition to semantic translation normally reduces the unit of translation, and brings the text closer to the figurative and formal elements of the original, including where possible its sound effects. Therefore, the text becomes more idiosyncratic and 'sensitive'. Length of sentences, however long or short, position and integrity of clauses, word-position for emphasis, are preserved, unless the divergence between the relevant norms of the source and target languages...is extensive. (ibid: 44)

Translators may justifiably opt for the semantic approach to spotlight a certain aspect that they deem important to the literary work they are entrusted to translate. This entails that they may retain the local flavor of the original and some culture-bound features. In so doing, translators should be duty-bound to utilize all possible means to render the literary work intelligible to the target recipients. Newmark endorses this view:

Original expression, where the specific language of the speaker or writer is as important as the content, whether it is philosophical, religious, political, scientific, technical or literary, needs to be translated semantically. Any important statement requires a version as close as to the original lexical and grammatical structures as is obtainable. (44)

The following example attests to the fact that the semantic approach can be adopted to fulfill a certain purpose:

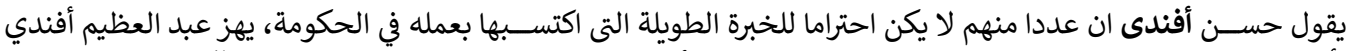

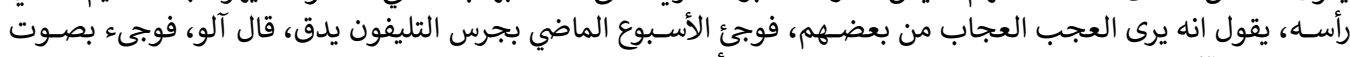

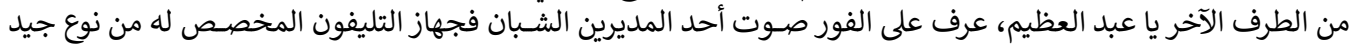




$$
\begin{aligned}
& \text { يوضح الأصوات تماما، رد عليه: عبد العظيم أفندى من فضلك. تساءل الشـاب: ما الفرق؟ قال ان الفرق كبير، عليه تعلم }
\end{aligned}
$$

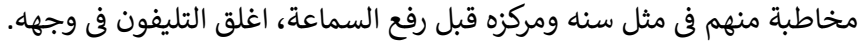

Hasan Effendi said that some directors had no respect for the long experience that one acquired working for the government. Abdel Azim Effendi shook his head, saying that he had indeed recently witnessed certain directors doing strange things. He had been surprised last week when his telephone had rung. He had said hello, and had been shocked when a voice at the other end said, "Abdel Azim?" He immediately recognized the voice of one of the young directors-his telephone being of such a good quality that one could distinguish voices clearly. He replied, "Abdel Azim Effendi, if you please!" The young man wondered what difference that made, and Abdel Azim Effendi replied that it made a big difference, that he should learn how to address people of his age and station before lifting the receiver, and promptly hung up. (The Zafarani Files, 52)

Evidently, the translator, Abdel Wahab, has made no effort to shift the honorific "Effendi" into the target cultural context, for he knows that Al- Ghitani, through this novel, attempts to paint a true picture of the Egyptian society at that time. He deftly retains "Effendi" and furnishes the readers with a footnote detailing its significance to aid El Ghitani in articulating a critique of the Egyptian society that was plagued with class distinctions. Replacing "Effendi" with "Mr." would not have triggered the same effect on target recipients.

Further, the semantic approach may stand the translator in good stead in legal translation where precision of expressions and accuracy of terminology are highly required. In legal translation, for instance, every word should be translated to plug the loopholes that may surface if the receiver does not assimilate every word of the legal text. Also, in documentary translation, the semantic approach is widely used to avoid any inaccuracies. Nord (1997) outlines the merits of the semantic approach stating that "there are many cases where relative literalism is precisely what the receiver (or the client or the user) needs, for example in the translation of a marriage certificate or driver's license, foreign legal texts for comparative purposes or direct quotations in newspaper reports" (29).

\section{Communicative Approach and Culture}

The communicative approach, on the other hand, sets great store on the target reader and the response of the receptor. It attempts to generate a meaning that will elicit a response from the target recipients that approximates the response of the $S L$ readers. It also advocates the equivalent-effect principle of translation which tends to dismiss the predominance of words and structure. To this effect Newmark states that

Communicative translation attempts to produce on its readers an effect as close as possible to that obtained on the readers of the original. Semantic translation attempts to render, as closely as the semantic and syntactic structures of the second language allow, the exact contextual meaning of the original. (Ibid: 39)

It is thus reader-centered, for it seeks to remove all the obscurities which impair the readers' understanding of the TT. The translator is given a free rein to adjust the logic and style of the original and clear up the ambiguities as well as jargons simply because the form of the ST invariably mirrors SL conventions that are almost at variance with TT norms. Hatim and Mason (1997) elucidate the translator's communicative role:

To say that translators communicate may perhaps strike one a fairly obvious claim to make. Yet, it is this very quest for the successful exchange of meanings that is at the heart of what we pursue as professional or trainee translators, teachers or critics of translation. (14)

Adopting communicative translation, translators attempt to reproduce a text that conforms to the cultural matrix of the TT. That is to say, they adapt the SLT to the social and cultural norms of the TT so as to create an idiomatic, fluent text. The following two examples attest to this fact 


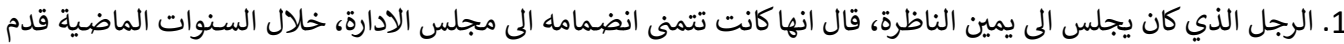

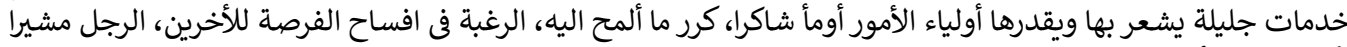
بأصبعه لكن أنفاسك ستظل

1. The man who had sat on the right of the headmistress said she had wanted him to be on the board of directors, as he had rendered great services to the school over the last few years-duly and properly appreciated by the parents. He nodded in thankfulness, repeating that he wanted to give the others a chance. Pointing with his finger the man said, "but you will be with us in spirit, won't you?" (A Distress Call, 182)

2. تؤمن أمه أن بركة الشـيخ سـتعيده يوما، سـيطرق الباب وعندما تفتحه سـتجد ابنها بلحمه ودمه، سـيرسـو فى احضـانها،

2. The mother believes that the sheikh's blessing will one day bring her son back. He will knock on the door, and when she opens it she will see her son in the flesh and he will rest in her arms and cry out, "Mama!" and she will kiss him and he will whisper "being away has killed me." (The Zafarani Files, 69)

In these two instances, the translators deftly depart from the letter of the source text in order to ensure an adequate communicative response in readers of the translation. In the first example, the translator replaces أنفاسك ستظل معن "but you will be with us in spirit, won't you?" to render the ST accessible to the target recipients. Had she adopted the semantic approach, she would have come up with an alien expression that would have impaired the target recipients' understanding of the intended meaning, as this approach gives precedence to words over meaning. Newmark maintains:

Communicative translation, however, is concerned with the receptors, usually in the context of a language and cultural variety, whilst semantic translation is concerned with the transmitter as an individual and often in contradistinction with both to his culture and the norms of his language. (Ibid: 43)

In the second example, the translator dexterously comes up with the equivalent idiom, deliberately omitting the word dog, as the English idiom does not include it. Had he retained it, he would have come up with an idiom alien to the English culture. In communicative translation, the translator intervenes in the text to relay the message across linguistic and cultural boundaries. Opting for omission, or under translation, as Newmark puts it, to create a readable and fluent text is symptomatic of the communicative approach. He asserts " Generally, a communicative translation is likely to be smoother, simpler, clearer, more direct, more conventional, conforming to a particular register of language, tending to under translate, i.e. to use more generic, hold-all terms in difficult passages"(Ibid: 39).

One can safely assume that there is a reciprocal relationship between the communicative approach and the principle of acceptability of translation. This principle means that the target text must sound idiomatic enough to the reader of translation. It requires a good deal of adjustment and editing. The process of adjustment and editing involves the restructuring of sentences, adding clarifications as well as omitting anything thought to hamper the easy flow of thought. In the above-mentioned examples, the translators under study have omitted the Arabic idioms and replaced them by their equivalents so as to retain the fluency of the text. The translator has to be cautious that his/her omission does not impinge on the accuracy of rendering. Accuracy can never be sacrificed in the search for acceptability. Baker (1981) alerts translator that "accuracy is no doubt an important aim in translation, but it is also important to bear in mind that the use of common target-language patterns which are familiar to the target reader plays an important role in keeping the communication channels open" (57).

\section{The Problem of Equivalence in Translation}

Newmark's semantic and communicative approaches bear resemblance to Nida's (1964:59) categorization of equivalence, namely, formal and dynamic equivalence. Akin to the semantic approach, formal equivalence manifests the features of the source culture without any degree of adjustment, that is, the translator does not take pains to adapt it to the circumstances of the target culture. In transferring formal equivalence, the translator's main concern is to reveal the message of the source text in form and content. Nida and Taber (1982) thus maintain that formal equivalence is the "quality of a translation in which 
features of the source text have been mechanically reproduced in the receptor language" (201). The following example illustrates how it is employed by translators:

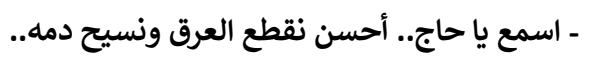

"It's best to cut the vein and let it bleed!" (A Distress Call, 59)

Apparently, words are "sacred", in adopting Nida's formal equivalence, as Newmark puts it in describing the semantic approach. Naguib has advocated Nida's formal equivalence presumably because she wanted to impart the flavor of the Egyptian culture to the receptors. However, being adherent to the source culture, she has come up with a culturally odd idiom that has a confounding effect on the receptor. This undoubtedly underlines the fact that adopting such equivalence is apt to fail to reproduce some elements in the literary texts such as idioms, and puns simply because they are unique to source language culture. Hence, the tendency toward this type of equivalence, according to Nida and Taber (1982) "distorts the grammatical and stylistic patterns of the receptor language, and hence distorts the message" (20).

Further, the afore-mentioned example highlights the fact that adhering to literalness is not synonymous with accuracy since it is not wholly correct to assume that a word for word translation of a source text renders precisely the same semantic range as the original. Barnston (1993) draws the translator's attention to the fact that "the virtue of reproducing similar word order is not a literalist sign of accuracy but a literary means of reproducing foreign flavor in the target language. So in theory and in ordinary practice the premise that literalism equals accuracy, and absolute literalism equals accuracy... is absolutely false" (38). Hence, the need arises when the translator adopts this type of equivalence to supplement his/her translation with footnotes explicating the source culture features to the receptors. The example at hand is a case in point, as the translator furnishes the receptors with a footnote giving the equivalent of the Egyptian idiom. She transforms the idiom into "it is best to make a clean break." Nida (1964) recommends the use of footnotes to strike a balance between the form and the content of the translation. He argues:

A consistent formal equivalence translation will obviously contain much that is not readily intelligible to the average reader. One must therefore usually supplement such translations with marginal notes, not only to explain some of the formal features which could not be adequately represented, but also to make intelligible some of the formal equivalents employed for such expression may have_significance only in terms of the source language and culture.

House (1986) recommends employing Nida's formal equivalence, calling it Overt Translation that is when the ST has "a firm anchoring in the source culture" (188). That is to say, if the ST represents some intrinsic and deep-rooted values of the source culture, the translator may not resort to cultural realignment to render them perfectly intelligible to receptors; rather s/he may preserve them and furnish the receptors with explanatory notes highlighting cultural distinctiveness. Similarly, Hatim and Mason (1990) concur with the view that the target recipients stand to benefit from adopting formal equivalence, as they may be willing to savour the flavor of the source language and its distinctiveness. They maintain:

Formal equivalence is, of course, appropriate in certain circumstances. At crucial points in diplomatic negotiations, interpreters may need to translate exactly what is said rather than assume responsibility for reinterpreting the sense and formulating it in such a way as to achieve what they judge to be equivalence of effect..., in other words [it is] a means of providing some degree of insight into the lexical, grammatical or structural form of a source text. (7)

On the other hand, Nida's dynamic equivalence, like the communicative approach, accords the translator more freedom to depart from the lexis and structure of the source text to produce a text whose effect is similar or equivalent to the effect of the source text on the original reader. Nida and Taber argue that dynamic equivalence is the quality which characterizes a translation in which "the message of the original text has been so transported into the receptor language that the response of the receptor is essentially like that of the original receptors."(200). Dynamically equivalent translation is produced in accordance with Nida's three-way process of translation which includes Analysis, Transfer, and Restructuring. 


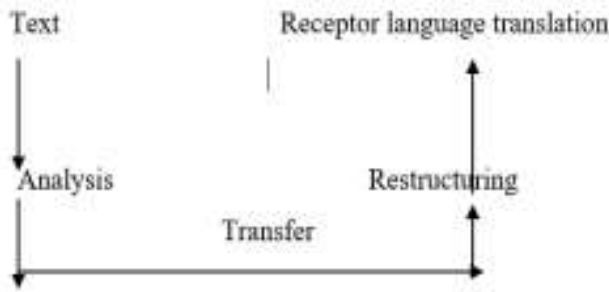

Such a process entails that the translator substitutes TL features which are more culturally appropriate for obscure ST items, thus rendering linguistically implicit ST information explicit. In other words, the translator endeavors to relate the receptor to social norms relevant and familiar to his/her cultural milieu without insisting that $s /$ he comprehend the cultural patterns of the source language. Hatim and Mason (1990) maintain that "orientation towards dynamic equivalence, on the other hand, is assumed to be the normal strategy. Although most translations may fall somewhere on the scale in between the two types, Nida claims that the present direction is toward increasing emphasis on dynamic equivalences" (7).

Therefore, a translation of dynamic equivalence will communicate less about the cultural frame in which the source text belongs than a translation of formal equivalence. In the former, discrepancies between cultures are diminished, so that the readers can achieve a good understanding of the message without necessarily having or acquiring knowledge of the source culture. The latter will not attempt to narrow the gap between the two cultural contexts involved, and will hence convey more information about the source culture, at the same time it keeps closely to the nuances of the source language such as idioms and proverbs. Hatim and Munday (2004) alert translators to the fact that

An important point to underline here is that opting for this or that form of equivalence is not an either/or choice. The distinction dynamic vs. formal equivalence (dynamic vs. structural correspondence) is best seen in relative terms, as points on a cline. The two methods are not absolute techniques but rather general orientations. In fact, what experienced translators seem to do most of the time is to resort to a literal kind of equivalence initially, reconsider the decision in the light of a range of factors, and ultimately make a choice from literal, formal or dynamic equivalence in this order and as appropriate. (43)

Similar to Newmark's communicative approach, Nida's dynamic equivalence suppresses the features of the source culture for the sake of fluency. The target recipients may not stand a chance of savouring the source culture, for this technique, like Newmark's approach, presumes that the form of the SLT is unimportant. Thus, it can be considered an act of cultural appropriation: the translator appropriates the cultural features characteristic of the source language, and transforms them into the target language, providing no room for the receptors to ponder the source culture with its peculiarities. Fawcett (1997) argues that

Another charge now made against Nida by the multiculturalists is that if we follow his injunction to preserve the genius of the target language, it will mean suppressing the otherness of the source language and so is a form of colonialism or 'ethnocentric violence' ... The problem with the concept of dynamic equivalence does indeed appear most acutely when it produces what seem to be colonizing translations. (58)

House refers to Nida's dynamic equivalence, calling it Covert Translation: she expounds that the purpose of this type of translation is to produce a TT which is "as immediately and 'originally' relevant as it is for the source language addressees" (Ibid: 188). The production of a covert translation can therefore be viewed as an attempt to conceal the translated nature of a TT by producing a text which is functionally equivalent to ST. According to House, such an approach is appropriate for STs which have no independent status in the source culture, or which are not inextricably associated with culture. She also recommends using a "cultural filter" to produce a TT equivalent to the ST.

In the same connection, Nord (1991) employs the term "Instrumental Translation" to refer to Nida's dynamic equivalence. She maintains that this type of translation is intended to "to fulfill a new communicative purpose in the target culture without the recipient being conscious of reading or hearing a text which, in a different form, was used before in a different communicative action" (73). Nord's concept of Instrumental translation differs slightly from House' concept of Covert Translation in that it only 
requires the $T T$ function to be compatible rather than equivalent. However, on the whole, Nida's dynamic equivalence gave rise to both Covert and Instrumental Translations.

The resolution of the conflict between the formal and dynamic equivalence seems increasingly to favour the latter, especially in the translating of poetic materials. Venuti (2000) subscribes to C.W. Orr's view of the translational process, as the latter believes that translating is somewhat equivalent to painting "the painter does not reproduce every detail of the landscape"s/he selects what seems best for him/her. Likewise, for the translator, "it is the spirit, not only the letter that he seeks to embody in his own version."(318). He also quotes Oliver Edwards upholding the same point of view: "we expect approximate truth in a translation... what we want to have is the truest possible feel of the original. The characters, the situations, the reflections must come to us as they were in the author's mind and heart, not necessarily precisely as he had them on his lips" (13).

\section{Functional Approach and Culture}

The common denominator in Newmark's approaches and Nida's categorization of equivalence could be that both of them pay little attention to what prompts the translator to adopt either of the techniques. That is to say, both of them fall short of emphasizing the function or the purpose which the translator seeks to fulfill. The function or the purpose which the translation seeks to fulfill undoubtedly determines the choice of the translation approach.

The functional approach can be regarded as the optimal one to be adopted in translation since it combines the merits of both the semantic and communicative approaches and occupies a middle ground between formal and dynamic equivalence. This approach sets a balance between these two approaches and the two types of equivalence in the translation process. In other words, it entails that the translator employs either the semantic approach or the communicative in accordance with the purpose which the translation seeks to fulfill. Gentzler (2001) argues that

The emergence of a functionalist translation theory marks an important moment in the evolution of translation theory by breaking the two-thousand-year-old chain of theory revolving round the faithful vs. free axis. Functionalist approaches can be either one or the other and still be true to the theory, as long as the approach chosen is adequate to the aim of communication.

To functionalists, what renders the translated text acceptable is whether it is fit for a designated purpose; in the words of Nord (1997) "the ends justify the means" (29). The primary aim of the translator is to fashion a target text that is functional in the target audience's community: achieving fluency can be of a lower priority. Nord asserts:

Functional translation does not mean that source-culture conventions must be replaced by target-culture conventions in each and every translation. Depending on the translation purpose and type, the translator may opt for reproduction and adaptation. There are also translation tasks where some kinds of convention have to be reproduced whereas others should be adjusted to target-culture standards. (Ibid: 57)

This approach draws upon the Skopostheorie, which was set forth by Vermeer in 1989. It propounds that every translation has a skopos: it is a Greek word for 'purpose'; the purpose of the translation is instrumental in making the translator select the appropriate approach of translation. That is to say, if the purpose intended from the translation is to make the target reader savour the Source Language, the translator should opt for the semantic approach, though the target reader may not understand the text. On the other hand, if the purpose of translation is to enable the target readers to comprehend the message in an intelligible manner, the translator should opt for the communicative approach. Therefore, the translator is entrusted with the responsibility of choosing the appropriate approach of translation in light of the purpose and details provided to him/her. Nord highlights the importance of Skopos by saying:

Evidently, the skopos often has to be negotiated between the client and the translator, especially when the client has only a vague or even incorrect idea of what kind of text is needed for the situation in question. Clients do not normally bother to give the translator an explicit translation brief; not being experts in intercultural communication, they often do not know that a good brief spells a better translation. (Ibid:30) 
Vermeer (1987) argues that to translate is "to produce a text in a target setting for a target purpose and target addressees in target circumstances" (29). Similarly, Nord (2000) does not approve of having more than one skopos or skopoi for a translated text lest this should distort the translation and confound the receptor. The skopos should be determined beforehand by what Vermeer calls a "commissioner" or the "initiator" often depicted as the sponsor of translation that is requested. She asserts that

If a text is to be functional for a certain person or group of persons, it has to be tailored to their needs and expectations. An "elastic" text intended to fit all receivers and all sorts of purposes is bound to be equally unfit for any of them, and a specific purpose is best achieved by a text specifically designed for this occasion. (195)

The following specimen text convincingly demonstrates how the translator, Abdel Wahab, has put the skopos theory into practice:

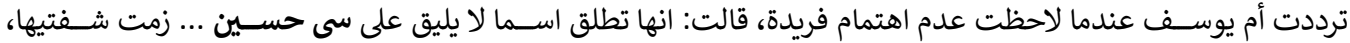

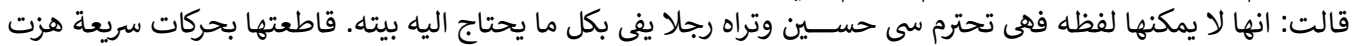

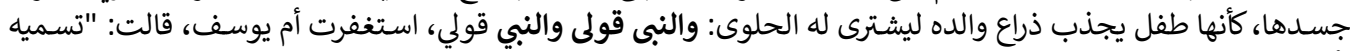

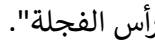

Umm Yusif hesitated when she noticed that Farida showed no interest in what she was saying, but she added that Busayna had called Master Hussein an improper name. She pursued her lips, saying that she could not repeat that name since she saw in him a good man who provided everything that his household required. Farida interrupted her with quick movements that shook her body as if she were a child tugging at her father's arm to buy her some candy. "For the sake of the Prophet, please, please tell me."Umm Yusif asked God's forgiveness and said, "She called him "Radish head". (The Zafarani Files, 25)

Having scooped the Saif Ghobash-Banipal Prize for Arabic Literary Translation because he dexterously imparts the Arabic culture flavour to the receptors, Abdel Wahab does not dispense with the cultural features that enable the receptors to savour the Arabic culture. In the specimen text at hand, he replaces wى wسين with Master Hussein to palpably demonstrate how women in Arab societies confer a great deal of respect on men since Arab societies are male-dominated. Had he opted for Mr. Hussein, he would not have driven this point home since the word "Master" piques the receptor's curiosity to know why he and other men deserve such a title. Abdel Wahab also retains والنبى قولى and translates it into "For the sake of the Prophet" to underscore the elevated status Prophet Muhammad holds in the hearts of Egyptians. Had he replaced it with for goodness sake or God's sake, he would have produced a fluent text that does not reflect the Egyptian culture. Nord (1997) highlights the role of the translator within the framework of Skopostheorie:

Guided by the translation brief, the translator selects certain items from the source-language offer of information (originally meant for source-culture addressees) and processes them in order to form a new offer of information in the target language, from which the target-culture addressees can in turn select what they consider to be meaningful in their situation. (32)

The American University in Cairo, the commissioner, according to functionalist theory, must have tasked the translator with translating this work of art, designating the purpose of imparting the Arabic culture flavor to the receptors. The functionalist theory points up cultural distinctiveness provided that it is demanded by the commissioner / initiator. Nord (1991) points out:

Translation is the production of a functional target text maintaining a relationship with a given source text that is specified according to the intended or demanded function of the target text (translation skopos). Translation allows a communicative act to take place which because of existing linguistic and cultural barriers would not have been possible without it. (28)

Further, the afore-mentioned example thrusts into focus two other pillars of the Skopostheorie, beside the Skopos, namely, coherence and culture. As for coherence, it is divided into two types: intratextual and intertextual. Intratextual coherence assumes that for a translation to be accepted and used by target recipients, it must fit within their cultural matrix; that is, it 
must cohere with their cultural expectations to the extent that they comprehend it given their particular cultural knowledge and situational circumstances. To clarify, in the above-mentioned example, though the translator preserves some cultural features pertaining to the Egyptian culture, he produces a readable and comprehensible text to the receptors. Nord (1997) elucidates this point as follows:

The target text makes sense within the communicative situation and culture in which it is received. The coherence rule states that the translation should be coherent with or acceptable in the receiver's situation, that is to conform to the conventions established in the target culture for the text type in question. (108)

As for intertextual coherence or fidelity, it entails that the translator pays heed to the source text and does not distort it on the pretext of producing a fluent text. Translators are morally obliged to deliver the meaning to their partners in the communication action by translating in the manner that is consistent with their request. That is to say, translators are not at liberty to come up with randomly re-edited versions of the source text or manipulate the receptors with translations which unfairly distort the original. Intertextual coherence has been observed in the afore-mentioned example by retaining the cultural features of the source culture. Nord asserts that

For example, if the target culture expects a translation to be a literal reproduction of the original, translators cannot simply translate in a non-literal way without telling the target audience what they have done and why. It is the translator's task to mediate between two cultures, and mediation cannot mean imposing one's culture-specific concept on members of another community. (Ibid: 125)

Nord (1997) pinpoints a number of suggestions for a skopos-based/purpose-oriented approach to literary translation: “(1) The translator's interpretation should be identical with the sender's intention. (2) The translator should verbalize the sender's intention in such a way that the target text is able to achieve the same function in the target culture as that which the source text achieved in the source culture. (3)The target receiver should understand the text world of the translation in the same way as the source receivers understood the text world of the original. (4) The effect the translation has on its reader should be the same as the one the source text has or had on its original readers." (92)

The third pillar of the Skopostheorie to be observed in the afore-mentioned example is culture. It underscores the role of the translator as a mediator who devises ways and means to transcend cultural barriers. Nord maintains that "According to Vermeer, every cultural phenomenon is assigned a position in a complex system of values, it is 'evaluated'. And every individual is an element in a system of space-time coordinates. If this is accepted, transcultural action or communication across cultural barriers has to take account of cultural differences with regard to behavior, evaluation and communicative situations" (Ibid:33). To put it more clearly, the translator in the previous example has put the cultural difference into his consideration, paying attention to coherence, he deftly retains them and maintains the readability of the TT.

\section{Criticisms of Skopostheorie and the Functional Approach}

Though the skopostheorie has won the acclaim of many translation theorists and practitioners, it has also drawn some criticism. Newmark (2002) dismisses the theory as of no great consequence, claiming that it is axiomatic that all translations have a purpose. He contends that, "anybody would agree that you need to know why you are doing something, as well as what you are doing and how you want to do it, and that sometimes if you get too involved, you tend to forget what your aim is ... But to translate the word aim into Greek, and make a theory of it, and to exclude any moral factor except loyalty... is pretending too much and going too far" (83). However, it is worth noting that Newmark has not placed much emphasis on when and what for to use his semantic and communicative approaches.

Another criticism leveled at Skopostheorie is that it tends to complicate the translational process by introducing unnecessary terms. Newmark (2002) contends that "it is merely common sense that in order to do anything well, you have to know why you are doing it... but to blow this up into a theory of translatorial action, where the aim becomes a skopos, the translation a translatum, the occasion a commission, the reader a consumer...hardly constitutes an original theory of translation" (106). This criticism can be countered by stating that these terms represent the pillars of the translational process. Each one has an indispensable function. 
Another criticism leveled at the Skopostheorie is that its success depends totally on the satisfaction of the brief offered by the commissioner, as this diminishes the role of the translator as the bi-cultural mediator, and grants exclusive powers to the commissioner. The commissioner may not be cognizant of the cultural and linguistic discrepancies existing between the ST and the $T$, and may, in the light of this, give the translator the wrong brief, thus endangering the intelligibility of the translation and consequently its success. Therefore, it is imperative that the translator gives his/her opinion to the commissioner, and not blindly follow what is dictated by his/her brief. Koller (1995) rightly points out:

On the basis of modern translation theory, we can talk of 'translation' when a source text (of oral or written nature) has, for a particular purpose, been used as a model for the production of a text in the target culture. As a translator I am also in a position to judge when a source text is unsuitable as model for a target culture text, and to propose to the client the production of a new text for the target culture. (194)

Another criticism closely linked with the previous one is that it justifies any translation since the translator is guided by the brief of the commissioner. In this sense, the translator may justifiably deflect any criticism level at his work under the pretext that $\mathrm{s} / \mathrm{he}$ is merely following the brief dictated to him/her by the commissioner. Nord (1997) argues that, "the function -plus-loyalty model is also an answer to those critics who argue that the functional approach leaves translators free to do whatever they like with any source text, or worse, what their clients like" (127).

Some critics view Skopostheorie as a theory of adaptation, that is, when the TT suppresses the intrinsic features of the source culture for the sake of intelligibility. Newmark (2002) maintains that "far from dethroning the source language text, rejecting it, deverbalizing it, vaporizing it, transforming it, ignoring it, I look hard at it. If it is good, I want to render it accurately through translation; if it is defective, I want to expose it through translation" (105). This criticism can be countered by stating the incontestable fact that intelligibility and familiarity on the part of the recipients ensure the exposure and success of translation. Hermans (1985) maintains that

Taking the supremacy of the original for granted from the start, the study of translation then serves merely to demonstrate that original's outstanding qualities by highlighting the errors and inadequacies of any number of translations of it. The outcome, needless to say, is an invariably source-oriented exercise, which, by constantly holding the original up as an absolute standard and touchstone, becomes repetitive, predictable and prescriptive. (8)

\section{Conclusion}

This research excludes the possibility of having an all-purpose translation approach. It highlights the importance of the functional approach to translation which is based on the Skopostheorie as the optimal approach, for it strikes a balance between Newmark's approaches and gives priority to the function the translated text is intended to fulfill. It could be safely considered the modus operandi of the translational process because it resolves the age-old polemical issue of choosing either literal or free translation, semantic or communicative approach. According to the skopos theory, translation is not all about linguistic transcoding, or cultural transference, rather it is a communicative action determined by a purpose.

Although the Skopostheorie has drawn many criticisms, some of them have been refuted; it is practically useful to adopt it provided that the translator should voice his/her opinion which is soundly based on his/her expertise and does not follow blindly what the commissioner/client dictates to him/her. A discussion should be held prior to setting out to translate the ST in order to sound out the view of the client and the translator should offer to advise him/her on the end product. This research prepares the ground for further research in the field of translation as most of the strategies employed are directed towards novels and short stories; however, drama and poetry may not stand to benefit from these strategies. Al-Ghitani's literary works may whet the appetite of more researchers to investigate the question of the representation of culture and the optimal translation strategy due to the fact they are larded with culture-specific elements that pique the curiosity of all those interested in the Egyptian culture in particular and cross-cultural communication in general. 


\section{References}

[1] Al-Ghitani, G. (2004). Zayni Barakat. Cairo: The American University in Cairo Press.

[2] Al-Ghitani, G. (2009). The Zafarani Files. Cairo: The American University Press.

[3] Al-Ghitani, G. (1997). A Distress call. Cairo: State Publishing House.

[4] Baker, M. (1992). In Other words: A Coursebook on Translation. London: Routledge.

[5] Barnstone, W. (1993). The Poetics of Translation: History, Theory, Practice. New Haven and London: Yale University Press.

[6] Beekman, J, and Callow J. (1974). Translating the Word of God. Michigan: Zondervan.

[7] Beeby, Al. (2000). Investigating Translation. Amsterdam and Philadelphia: J. Benjamins.

[8] Brown, G. A Practical Guide for Translators. (2004). UK: Clevedon Hall.

[9] Bassnett, S, \& Lefevere, A. (1990). Translation, History and Culture. London and New York: Pinter.

[10] Fawcett, P. Translation and Language: Linguistic Theories Explained. (1997). Manchester: St. Jerome.

[11] Gentzler, E. (2001). Contemporary Translation Theories.2 $2^{\text {nd }}$ edn. Clevendon: multilingual Matters.

[12] Hatim, B, \& Mason,I. (1990). Discourse and the Translator. London: Longman.

[13] Hatim, B \& Mason I. (1997). The Translator as Communicator. London and New York: Routledge.

[14] Hatim, B \& Munday, J. (2004). Translation: An Advanced Resource Book. London and New York: Routledge.

[15] Hermans, T. (1985). The Manipulation of Literature: Studies in Literary Translation. London: Croon Helm.

[16] House, J. (1986). Interlingual and Intercultural Communication. Tubingen: Gunter Narr Verlag.

[17] Koller, W. (1995). The concept of equivalence and the object of translation studies. Target. International Journal of

Translation Studies, 7(2), 191-222

[18] Landers, C. (2001). Literary Translation: A Practical Guide. Clevedon: Multilingual Matters Ltd.

[19] Newmark, P. (1988). A Textbook of Translation. New York: Prentice-Hall International.

[20] Newmark, P. (2002). The Deficiencies of Skopos Theory: A Response to Anna Trosborg, in C. Schaffner (ed.) 83-106.

[21] Nida, E. and Taber C. (1982). The Theory and Practice of Translation. Netherlands: Leiden, E.J. Brill.

[22] Nida, E. (1964). Toward a Science of Translating. Netherlands: Leiden, E.J. Brill.

[23] Nord, C. (1991). Text Analysis in Translation: Theory, Methodology and Didactic Application of a Model for Translation-oriented Text Analysis. Amsterdam: Rodopi.

[24] Nord, C. (1997). Translating as a Purposeful Activity: Functionalist Approaches Explained. Manchester: St. Jerome Publishing.

[25] Nord, C. (2000). What do We Know about the Target-Text Receiver? in A. Beeby Et al. (eds) 195.

[26] Rose, M. (1981). Translation Spectrum. New York: State University of New York Press.

[27] Schaffner, C. (2002). Translation and Quality. Clevedon: Multilingual Matters.

[28] Venuti, L. (2000). The Translation Studies Reader. USA and Canada: Routledge.

[29] Vermeer, H. (1987). What does it Mean to Translate? 13(2), 29.

\section{Arabic References}

[30] Al-Ghitani, G. (1993). nfț̈̈ mṣdūr. al-kwyt, dār s'ād al-șbāḥ.

[31] Al-Ghitani, G. (2008). ūqā'i' ḥārï al-z' frāni. al-qāhrï, dār al-šrūq.

[32] Al-Ghitani, G. (1989). al-zīnī brkāt. al-qāhrẗ, dār al-šrūq. 